\title{
Flavones from Combretum quadrangulare Growing in Vietnam and Their Alpha-Glucosidase Inhibitory Activity
}

\author{
Thi-Bich-Ngoc Dao ${ }^{1}$, Truong-Minh-Tri Nguyen ${ }^{1}$, Van-Quy Nguyen ${ }^{1}$, Thi-Minh-Dinh Tran ${ }^{2}$, \\ Nguyen-Minh-An Tran ${ }^{3}$ (D) Chuong Hoang Nguyen ${ }^{4}$, Thi-Hoai-Thu Nguyen ${ }^{5}$, Huu-Hung Nguyen ${ }^{6}$, \\ Jirapast Sichaem ${ }^{7}$, Cong-Luan Tran ${ }^{8, *}$ and Thuc-Huy Duong ${ }^{1, *}$
}

1 Department of Chemistry, University of Education, 280 An Duong Vuong Street, District 5, Ho Chi Minh City 72711, Vietnam; ngocdaosph@gmail.com (T.-B.-N.D.); nguyentruongminhtri99@gmail.com (T.-M.-T.N.); nguyenvanquysphoa@gmail.com (V.-Q.N.)

2 Department of Biology, Ho Chi Minh City University of Education, 280 An Duong Vuong Street, District 5 , Ho Chi Minh City 72711, Vietnam; dinhttm@hcmue.edu.vn

3 Industrial University of Ho Chi Minh City, Ho Chi Minh City 71420, Vietnam; trannguyenminhan@iuh.edu.vn

4 University of Science, Vietnam National University, Ho Chi Minh City 72711, Vietnam; nhchuong@hcmus.edu.vn

5 Faculty of Basic Sciences, University of Medicine and Pharmacy at Ho Chi Minh City, 217 Hong Bang Street, District 5, Ho Chi Minh City 72714, Vietnam; nguyenthihoaithu@ump.edu.vn

6 Faculty of Technology, Van Lang University, 45 Nguyen Khac Nhu, District 1, Ho Chi Minh City 71013, Vietnam; hung.nh@vlu.edu.vn

check for

updates

Citation: Dao, T.-B.-N.; Nguyen, T.-M.-T.; Nguyen, V.-Q.; Tran, T.-M.-D.; Tran, N.-M.-A.; Nguyen, C.H.; Nguyen, T.-H.-T.; Nguyen, H.-H.; Sichaem, J.; Tran, C.-L.; et al. Flavones from Combretum quadrangulare Growing in Vietnam and Their Alpha-Glucosidase Inhibitory Activity. Molecules 2021, 26, 2531. https://doi.org/10.3390/ molecules26092531

Academic Editor: Raffaele Capasso

Received: 11 April 2021

Accepted: 23 April 2021

Published: 26 April 2021

Publisher's Note: MDPI stays neutral with regard to jurisdictional claims in published maps and institutional affiliations.

Copyright: () 2021 by the authors. Licensee MDPI, Basel, Switzerland. This article is an open access article distributed under the terms and conditions of the Creative Commons Attribution (CC BY) license (https:// creativecommons.org/licenses/by/ $4.0 /)$.
7 Research Unit in Natural Products Chemistry and Bioactivities, Faculty of Science and Technology, Thammasat University Lampang Campus, Lampang 52190, Thailand; jirapast@tu.ac.th

8 Faculty of Pharmacy and Nursery, Tay Do University, Can Tho 94000, Vietnam

* Correspondence: tcluan@tdu.edu.vn (C.-L.T.); huydt@hcmue.edu.vn (T.-H.D.); Tel.: +84-903855528 (C.-L.T.); +84-919011884 (T.-H.D.)

Abstract: Combretum quadrangulare Kurz is widely used in folk medicine in Eastern Asia and is associated with various ethnopharmacological properties including hepatoprotective, antipyretic, analgesic, antidysenteric, and anthelmintic activities. Previous phytochemical investigations reported the presence of numerous triterpenes (mostly cycloartanes, ursanes, lupanes, and oleananes) along with dozens of flavonoids. However, the extracts of $C$. quadrangulare and isolated flavonoids have not been evaluated for their alpha-glucosidase inhibition. In the frame of our efforts dedicated to the chemical investigation of Vietnamese medicinal plants and their biological activities, a phytochemical study of the $\mathrm{MeOH}$ extract of the leaves of $C$. quadrangulare using bioactive guided isolation was undertaken. In this paper, the isolation and structure elucidation of twelve known compounds, 5-hydroxy-3,7,4'-trimethoxyflavone (1), ayanin (2), kumatakenin (3), rhamnocitrin (4), ombuin (5), myricetin-3,7,3',5'-tetramethyl ether (6), gardenin D (7), luteolin (12), apigenin (13), mearnsetin (14), isoorientin (15), and vitexin (16) were reported. Bromination was applied to compounds 2 and 3 to provide four new synthetic analogues 8-11. All isolated and synthesized compounds were evaluated for alpha-glucosidase inhibition and antibacterial activity. Compounds $\mathbf{4}$ and $\mathbf{5}$ showed moderate antibacterial activity against methicillin-resistant Staphylococcus aureus while others were inactive. All compounds failed to reveal any activity toward extended spectrum beta-lactamase-producing Escherichia coli. Compounds 2, 4, 6-9, and 11-14 showed good alpha-glucosidase inhibition with $\mathrm{IC}_{50}$ values in the range of 30.5-282.0 $\mu \mathrm{M}$. The kinetic of enzyme inhibition showed that 8 and 11 were noncompetitive type inhibition against alpha-glucosidase. In silico molecular docking model indicated that compounds $\mathbf{8}$ and $\mathbf{1 1}$ were potential inhibitors against enzyme $\alpha$-glucosidase.

Keywords: Combretum quadrangulare Kurz; flavonoid; alpha-glucosidase; antibacterial; molecular docking

\section{Introduction}

Combretum quadrangulare Kurz is widely used in folk medicine in Eastern Asia. The traditional uses have been corroborated by in vitro data of hepatoprotective, antipyretic, 
analgesic, antidysenteric, and anthelmintic properties [1,2]. In Vietnam, this plant was used as antihelmintic and antihepatitis agents [1,2]. Although former chemical studies on C. quadrangulare reported the presence of hundreds of triterpenes (cycloartanes, ursanes, lupanes, and oleananes), over 10 flavonoids were found from this bio-source [3-8]. Among the different organs of the plant, the leaves of $C$. quadrangulare attracted chemists to investigate. The crude $\mathrm{MeOH}$ extracts of the Vietnamese $C$. quadrangulare (leaves and seeds) showed a significant hepatoprotective effect, xanthine oxidase inhibition, and cytotoxicity against several cancer cell lines $[6,7,9,10]$. Up to now, ten flavones-combretol (from seeds and flowers); ayanin; 5-hydroxy-2-(4'-hydroxy-3',5'-dimthoxyphenyl)-3,7-dimethoxy4H-1-benzopyran-4-one (from flowers); kumatakenin; isokaempferide; 5,7,4'-trihydroxy3,3'-dimethoxyflavone, 5,4'-dihydroxy-3,7,3'-trimethoxyflavone; isoorientin; isovitexin $4^{\prime}$-methyl ether (from leaves); and vitexin (from leaves and seeds) - were isolated from the Vietnamese native plant $[2,6,7,9]$. These compounds showed a strong inhibitory effect on TNF- $\alpha$-induced cell death and mild to strong cytotoxicity against several cancer cell lines: 26-L5, HT-1080, HeLa, and A549 [2]. Nonetheless, the alpha-glucosidase inhibition and antibacterial activity of the extracts of $C$. quadrangulare and the isolated compounds have not been reported. As a continuation of our research focused on the diversity of bioactive metabolites from Vietnamese medicinal plants and their biological activity [10-13], a phytochemical study of the $\mathrm{MeOH}$ extract of the leaves of $C$. quadrangulare using bioactive guided isolation was undertaken. In this paper, the isolation and structural elucidation of twelve known flavonoids $(\mathbf{1}-\mathbf{7}, \mathbf{1 2}-\mathbf{1 6})$ are reported. Moreover, the electrophilic bromination was applied to compounds 2 and 3 to obtain four new analogues $8-11$. Their structures were elucidated by spectroscopic data analysis and comparison with literature data. The isolated compounds were evaluated for alpha-glucosidase inhibition and molecular docking studies were performed to elucidate the mechanisms of inhibition. All compounds were further assayed for their in vitro antibacterial activity against methicillin-resistant Staphylococcus aureus and extended spectrum beta-lactamase-producing Escherichia coli (ESBL-producing E. coli).

\section{Results and Discussion}

\subsection{Phytochemical Study and Derivatization of Compounds 2 and 3}

The crude $\mathrm{MeOH}$ extract was successively partitioned into $n$-hexane, $n$-hexane:EtOAc $(1: 1, v / v)$, and EtOAc to provide extracts H, HEA, EA, and $\mathrm{M}$, respectively. These fractions were evaluated for $\alpha$-glucosidase inhibition. The most active extract was HEA. This was fractionated by column chromatography (CC), providing the fractions P1-P9. Of these, P2 and $\mathrm{P} 9$ showed the strongest biological activity (see Table S6). Isolation and purification were performed on these fractions (see Experimental Section), affording compounds 1-7 and 12-16.

The crude extract were fractioned and purified using chromatographic techniques to furnish 5-hydroxy-3,7,4'-trimethoxyflavone (1) [14], ayanin (2) [15], kumatakenin (3) [16], rhamnocitrin (4) [17], ombuin (5) [18], myricetin-3,7,3',5'-tetramethyl ether (6) [19], gardenin D (7) [20], luteolin (12) [21], apigenin (13) [22], mearnsetin (14) [23], vitexin (15) [24], and isoorientin (16) [25] (Figure 1). These were identified by comparing their NMR spectra with published data (Tables S1 and S2). Among them, compounds 4-7 and 12-14 were reported for the first time from C. quadrangulare.

Compounds 2 and 3 were selected for bromination to obtain new flavones (Scheme 1). The reactions were conducted using hydrogen peroxide and potassium bromide in acetic acid (Scheme 1). As a result, compound 8 was prepared from 2 while products 9-11 were derived from 3. The isolated yields of these compounds were $35-93 \%$. The $1 \mathrm{H}$ NMR spectrum of 8 displayed two meta-coupled protons at $\delta_{\mathrm{H}} 7.88$ and 8.18, three methoxy groups at $\delta_{\mathrm{H}} 3.80$ and $3.97(\mathrm{x} 2)$, and one hydrogen-bond hydroxyl group at $\delta_{\mathrm{H}} 15.71$. NMR data of 8 and its mother compound 2 was highly similar. The differences are the disappearance of three aromatic protons $\left(\mathrm{H}-6, \mathrm{H}-8\right.$, and $\left.\mathrm{H}-5^{\prime}\right)$, indicating that three positions were brominated. Altogether, the chemical structure of $\mathbf{8}$ was elucidated as shown. The 
identification of compounds $\mathbf{9 - 1 1}$ was readily established on the basis of their ${ }^{1} \mathrm{H},{ }^{13} \mathrm{C}$ NMR, and HRESI mass spectra (Tables S3 and S4).<smiles>[R]c1cc(-c2oc3c([R])c([R])c([R])c(O)c3c(=O)c2[R])cc([R])c1[R]</smiles>

\begin{tabular}{|c|c|c|c|c|c|c|c|}
\hline Compound & $\mathbf{R}^{1}$ & $\mathbf{R}^{2}$ & $\mathbf{R}^{3}$ & $\mathbf{R}^{4}$ & $\mathbf{R}^{5}$ & $\mathbf{R}^{6}$ & $\mathbf{R}^{7}$ \\
\hline $\begin{array}{l}\text { (1) 5-Hydroxy-3,7,4'- } \\
\text { trimethoxyflavone }\end{array}$ & $\mathrm{OMe}$ & $\mathrm{H}$ & $\mathrm{H}$ & $\mathrm{H}$ & $\mathrm{OMe}$ & $\mathrm{H}$ & $\mathrm{Me}$ \\
\hline (2) Ayanin & $\mathrm{OMe}$ & $\mathrm{H}$ & $\mathrm{H}$ & $\mathrm{OH}$ & $\mathrm{OMe}$ & $\mathrm{H}$ & $\mathrm{Me}$ \\
\hline (3) Kuatakenin & $\mathrm{OMe}$ & $\mathrm{H}$ & $\mathrm{H}$ & $\mathrm{H}$ & $\mathrm{OH}$ & $\mathrm{H}$ & $\mathrm{Me}$ \\
\hline (4) Rhamnocitrin & $\mathrm{OH}$ & $\mathrm{H}$ & $\mathrm{H}$ & $\mathrm{H}$ & $\mathrm{OH}$ & $\mathrm{H}$ & $\mathrm{Me}$ \\
\hline (5) Ombuin & $\mathrm{OH}$ & $\mathrm{H}$ & $\mathrm{H}$ & $\mathrm{OH}$ & $\mathrm{OMe}$ & $\mathrm{H}$ & $\mathrm{Me}$ \\
\hline $\begin{array}{l}\text { (6) Myricetin-3,7,3',5'- } \\
\text { tetramethyl ether }\end{array}$ & $\mathrm{OH}$ & $\mathrm{H}$ & $\mathrm{H}$ & $\mathrm{OMe}$ & $\mathrm{OH}$ & $\mathrm{OMe}$ & $\mathrm{Me}$ \\
\hline (7) Gardenin D & $\mathrm{H}$ & $\mathrm{OMe}$ & $\mathrm{OMe}$ & $\mathrm{OH}$ & OMe & $\mathrm{H}$ & $\mathrm{Me}$ \\
\hline (8) 6,8,5'-Tribromoayanin & $\mathrm{OMe}$ & $\mathrm{Br}$ & $\mathrm{Br}$ & $\mathrm{OH}$ & $\mathrm{OMe}$ & $\mathrm{Br}$ & $\mathrm{Me}$ \\
\hline (9) 8-Bromokumatakenin & $\mathrm{OMe}$ & $\mathrm{H}$ & $\mathrm{Br}$ & $\mathrm{H}$ & $\mathrm{OH}$ & $\mathrm{H}$ & $\mathrm{Me}$ \\
\hline (10) 6-Bromokumatakenin & $\mathrm{OMe}$ & $\mathrm{Br}$ & $\mathrm{H}$ & $\mathrm{H}$ & $\mathrm{OH}$ & $\mathrm{H}$ & $\mathrm{Me}$ \\
\hline $\begin{array}{l}\text { (11) } 6,8,3^{\prime}, 5^{\prime}- \\
\text { Tetrabromokumatakenin }\end{array}$ & $\mathrm{OMe}$ & $\mathrm{Br}$ & $\mathrm{Br}$ & $\mathrm{Br}$ & $\mathrm{OH}$ & $\mathrm{Br}$ & $\mathrm{Me}$ \\
\hline (12) Luteolin & $\mathrm{H}$ & $\mathrm{H}$ & $\mathrm{H}$ & $\mathrm{OH}$ & $\mathrm{OH}$ & $\mathrm{H}$ & $\mathrm{H}$ \\
\hline (13) Apigenin & $\mathrm{H}$ & $\mathrm{H}$ & $\mathrm{H}$ & $\mathrm{H}$ & $\mathrm{OH}$ & $\mathrm{H}$ & $\mathrm{H}$ \\
\hline (14) Mearnsetin & $\mathrm{OH}$ & $\mathrm{H}$ & $\mathrm{H}$ & $\mathrm{OH}$ & $\mathrm{OMe}$ & $\mathrm{OH}$ & $\mathrm{H}$ \\
\hline (15) Vitexin & $\mathrm{H}$ & $\mathrm{H}$ & Glc & $\mathrm{H}$ & $\mathrm{OH}$ & $\mathrm{H}$ & $\mathrm{H}$ \\
\hline (16) Isoorientin & $\mathrm{H}$ & Glc & $\mathrm{H}$ & $\mathrm{OH}$ & $\mathrm{OH}$ & $\mathrm{H}$ & $\mathrm{H}$ \\
\hline
\end{tabular}

Figure 1. Chemical structures of 1-16.
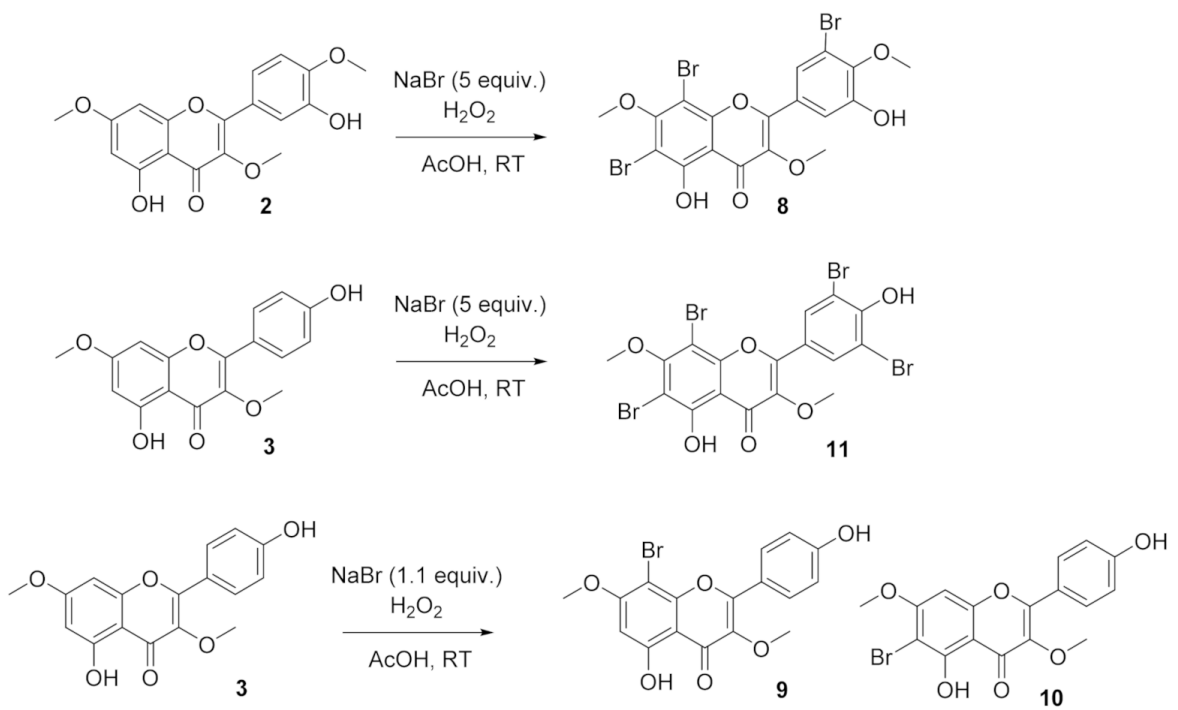

Scheme 1. General synthesis route towards analogues 8-11. 


\subsection{Alpha-Glucosidase Inhibitory Activity of Isolated Compounds}

The in vitro alpha-glucosidase inhibitory activity of 1-16 was evaluated (Table 1). Compounds 2, 4, 6-9, and 11-14 exhibited good inhibition of alpha-glucosidase with the $\mathrm{IC}_{50}$ values were in the range of 30.5 to $282.0 \mu \mathrm{M}$, greater than the standard, acarbose $\left(\mathrm{IC}_{50} 332.5 \mu \mathrm{M}\right)$. The C-3-substituted flavones 1-6 were relatively weaker than $\mathrm{C}$ 3-non-substituted analogues 7, 12, and 13, indicating the important role of the 3-H substituent in biological activity among flavones. As regards to the synthesized products, compounds 8-11 were more active than their parent compounds $\mathbf{2}$ and $\mathbf{3}$. The 6-brominated and 8-brominated products $\mathbf{9}$ and $\mathbf{1 0}$ were slightly stronger than their parent compound (3) whilst 11 significantly increased the activity $\left(\mathrm{IC}_{50} 30.5 \mu \mathrm{M}\right)$. This indicated the activity preference for the $3^{\prime} / 5^{\prime}$-bromo positions. Similarly, $6,8,5^{\prime}$-tribromoayanin (8) was stronger than the starting material $2\left(\mathrm{IC}_{50} 87.1 \mu \mathrm{M}\right)$. It is worth noting that the number of bromine atoms of the B-ring affected the biological activity.

Table 1. Alpha-glucosidase inhibitory $\left(\mathrm{IC}_{50}\right)$ of compounds 1-16. Values are means \pm standard errors of three independent experiments.

\begin{tabular}{cc}
\hline Compounds & IC $_{\mathbf{5 0}} \boldsymbol{\mu M}$ \\
\hline $\mathbf{1}$ & $>300$ \\
$\mathbf{2}$ & $245.3 \pm 3.7$ \\
$\mathbf{3}$ & $>300$ \\
$\mathbf{4}$ & $206.7 \pm 2.6$ \\
$\mathbf{5}$ & $>300$ \\
$\mathbf{6}$ & $282.0 \pm 2.9$ \\
$\mathbf{7}$ & $188.0 \pm 3.1$ \\
$\mathbf{8}$ & $87.1 \pm 2.3$ \\
$\mathbf{9}$ & $275.0 \pm 4.5$ \\
$\mathbf{1 0}$ & $>300$ \\
$\mathbf{1 1}$ & $30.5 \pm 1.9$ \\
$\mathbf{1 2}$ & $97.7 \pm 1.7$ \\
$\mathbf{1 3}$ & $130.8 \pm 3.9$ \\
$\mathbf{1 4}$ & $205.3 \pm 5.6$ \\
$\mathbf{1 5}$ & $>300$ \\
$\mathbf{1 6}$ & $>300$ \\
Acarbose & 332.5 \\
\hline
\end{tabular}

2.3. Inhibition Type and Inhibition Constants of the Compounds 8 and 11 on Alpha-Glucosidase

In order to examine the inhibition mechanism of compound 11, their activity was measured at the different concentration of $p$ NPG. The Lineweaver-Burk plots of a kinetic study of $\mathbf{8}$ and $\mathbf{1 1}$ showed linearity at each concentration examined $(0,4.96,9.92$, and $19.84 \mu \mathrm{M}$ for 8 and $0,21.62,43.03$, and $86.06 \mu \mathrm{M}$ for 11), which all intersected the $x$-axis in the second quadrant (Figure 2). The kinetic analysis revealed that $\mathrm{V}_{\max }$ decreased while $\mathrm{Km}$ remained constant, which showed that compounds $\mathbf{8}$ and $\mathbf{1 1}$ acted as noncompetitive inhibitors. The inhibition constants (Ki) of $\mathbf{8}$ was $39.82 \mu \mathrm{M}$ and that of $\mathbf{1 1}$ was $198.87 \mu \mathrm{M}$. 

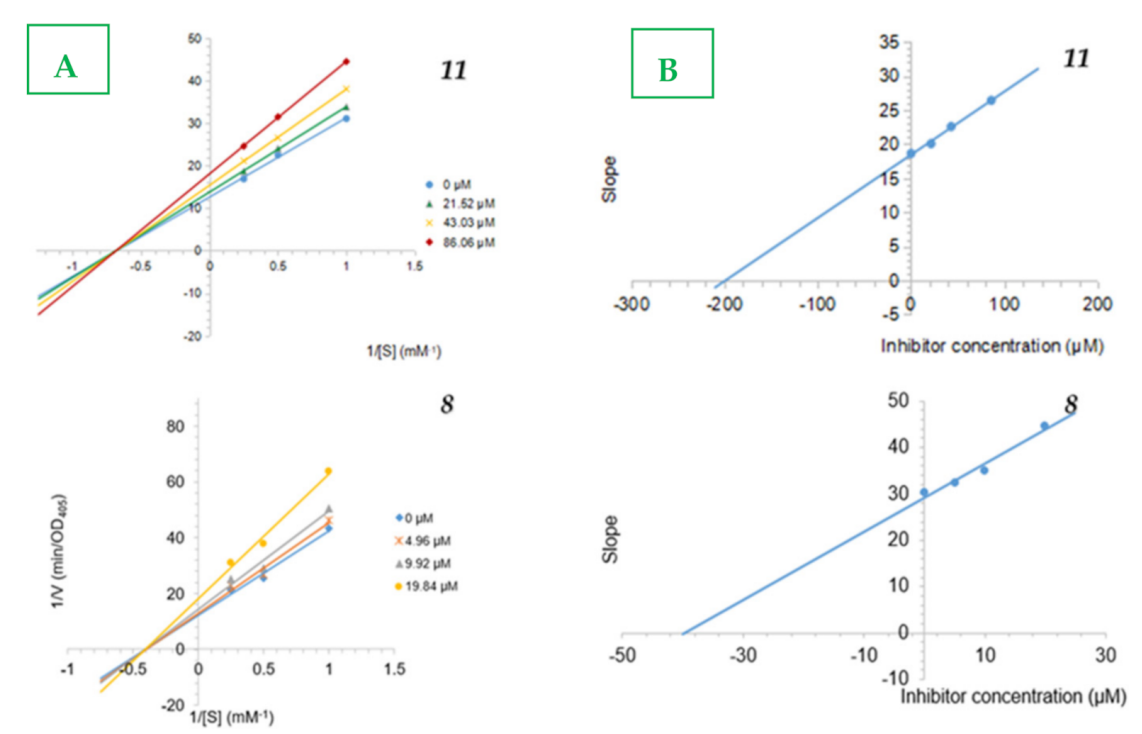

Figure 2. Lineweaver-Burk plot for $\alpha$-glucosidase inhibition by compounds $\mathbf{1 1}$ and $\mathbf{8}(\mathbf{A})$ and the secondary plot of slope vs. the inhibitor concentration (B).

\subsection{Antibacterial Activity of Isolated Compounds}

All compounds were evaluated for their in vitro antibacterial activity using the agar well diffusion method against methicillin-resistant Staphylococcus aureus (MRSA). Compounds 4 and 5 inhibited MRSA with diameters of inhibition zones of 14 and $15 \mathrm{~mm}$, respectively, at the quantity of $50 \mu \mathrm{g}$ for each compound, compared to that of the positive control, apramycin $(24 \mathrm{~mm})$. The others are inactive. All compounds failed to reveal any activity against ESBL-producing Escherichia coli.

\subsection{In Silico Molecular Docking Model}

The calculation results of molecular docking model of high active compound, 8, 11, and Acarbose based on autodock tools have been built in Figures 3-9, Figures S22-S27 and Table S5. In an in silico docking model, the most stable conformation of ligand $\mathbf{1 1}$ was bound to the active pocket on target enzyme 4J5T. Those interactions were assessed to be very strong because the values of Free Energy of Binding $\Delta G$ and the inhibition constant, $K_{i}$ between the most stable ligand $\mathbf{1 1}$ and target enzyme 4J5T have been calculated: $-9.45 \mathrm{Kcal} / \mathrm{mol}$ and $0.118 \mu \mathrm{M}$, as shown in Figure 3 and Table S5. As indicated in Figure 4 and Table S5, four hydrogen bonds linked from residuals amino acids of target enzyme to functional groups of ligand such as A:ARG428:N-11:O (2.91 $\AA$ ), A: ASN448:N-11: Br

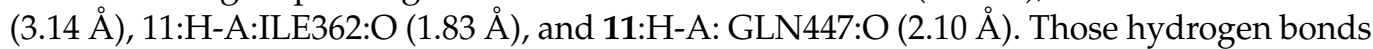
were formed with hydrogen atoms of phenolic hydroxyl and bromine atoms of aromatic rings. For the hydrogen linked from the bromine atom of ligand to the oxygen atom of ILE362 of amino acid of A chain, the receptor was the strongest hydrogen, $1.83 \AA$ among them. Those hydrogen bonds had hydrophilic interactions (green areas in Figure 3). As shown in Figure 5, the significant interactions were formed from active sites on the receptor to the most stable ligand such as classical hydrogen bonds; for instance, Asn 448 to bromo of phenyl ring, Arg 428 to oxygen of $\mathrm{OH}$ group of phenolic hydroxy, Val 446 to bromo atom of phenyl ring, Ile 362 to hydrogen atom of OH group of phenyl ring, and Gly 447 to hydrogen atom of phenolic hydroxy. Another non classical hydrogen bond was from Lys 363 to oxygen of hydroxy of phenolic hydroxy. The halogen interactions linked from Glu 429 and Gln 442 to bromine atoms of phenyl rings, respectively. The hydrophobic ligand interactions formed pi-sima from alkenyl group to Leu 364, pi-alkyl from Leu 364 to pi system of aromatic ring, and alkyl from Lys 363, Arg 428, and Phe 444 to the bromine atoms of aromatic rings. Other residual interactions were determined from Glu 361, Glu 443 , and Gln 445, which linked weak interactions to the wall of cells. Briefly, the ligand 11 was the potential delivery drug because it identified well functional groups (via hydrogen 
bonds, halogen bonds), cap groups (via pi-sigma, alkyl, pi-alkyl interactions), and other Van Der Waals interactions, which bound weak to the wall of cells, as shown in Figure 5. Other the secondary interactions, which formed between ligand 11 and receptor 4J5T, were hydrogen bond, steric, and overlap interactions. Those interactions have established the stable interactions of the conformation ligand and receptor, as indicated in Figure 6. Those steric interactions (light blue), which linked from residual amino acids of A chain of 4J5T to active site atoms on 11 were Ile 362, Val 446, Glu 443, Phe 444, Arg 428, and Asn 448. The hydrogen bond (brown color) formed from Ile 362 and Gln 447 to the most stable conformation ligand 11. The steric interactions show violet circles on atoms of the conformation ligand. The bigger the effect of the steric, the bigger the sizes of the violet circles were, as shown in Figure 6. The interaction profile between the most stable ligand 8 and target enzyme is built in Figures 7-9, Table S5. As shown in Figure 7, the most stable conformation ligand 8 was selected to link to the target enzyme on enzyme pocket. Those interactions were assessed with the value of Free Energy of Binding $\Delta G$ and the inhibition constant $\mathrm{K}_{\mathrm{i}}$, as shown in Figure 7 , and calculated as $-8.83 \mathrm{Kcal} / \mathrm{mol}$ and $0.337 \mu \mathrm{M}$. As indicated in Figure 8, two classical hydrogen bonds, which formed from hydrogen phenolic hydroxy to residual amino acid of target enzyme 4J5T, were established for instant 8:H-

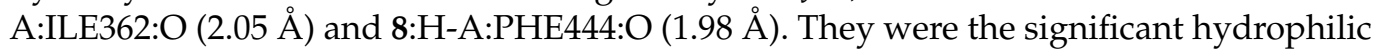
interactions, forming between ligand $\mathbf{8}$ and target enzyme. The interaction profile of the most stable conformation ligand 8 and enzyme is presented on a 2D diagram shown in Figure 9. As shown in Figure 9, ligand 8 has potential for drug delivery because it can be identified in a cap group (via ligand interactions such as pi-sigma: from Leu 364 to pi bound of alkenyl conjugation with ketone, mixed alkyl or pi-alkyl: from Leu: 364 to aromatic ring of ligand), linker (from Gln 447, Arg 428, Ile 362, Ile 364, Ile 451, Lys 363, Leu 365 , and Val 446 to methoxy groups, bromine atoms of ligand), and functional groups (Phe 444, and Ile 362). Other residual interactions, Van Der Waal interactions, formed around ligands (linked wall cell) such as Gln 442, Glu 443, Glu 429, Asn 448, and Glu 361). Both candidates have potential for drug delivery but $\mathbf{1 1}$ is superior to $\mathbf{8}$ because of the values of $\Delta \mathrm{G}$ and $\mathrm{Ki}$.

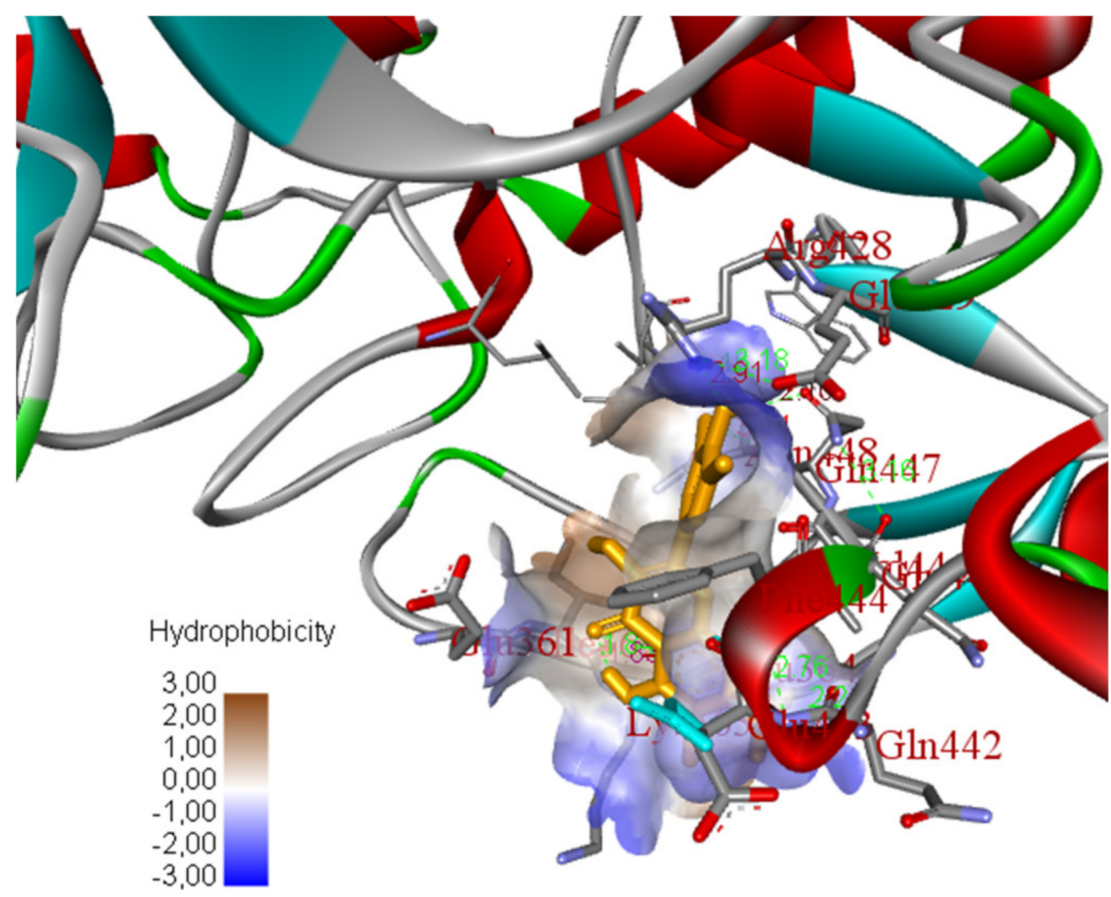

Figure 3. The most stable conformation ligand $\mathbf{1 1}$ was docked to active sites of enzyme and pocket enzyme of 4J5T: PDB (ligand: brown color). 


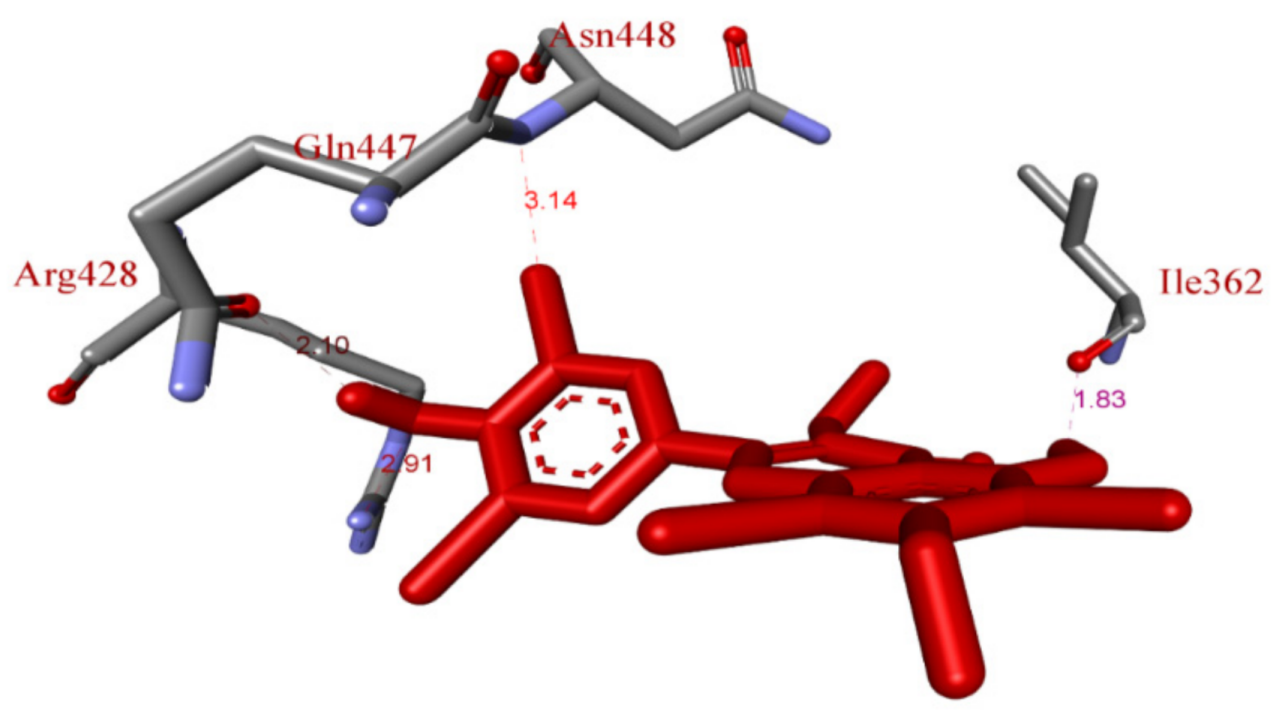

Figure 4. The hydrogen bonds were formed from residual amino acids of the target enzyme 4J5T to functional groups on the most stable conformation ligand $\mathbf{1 1 .}$

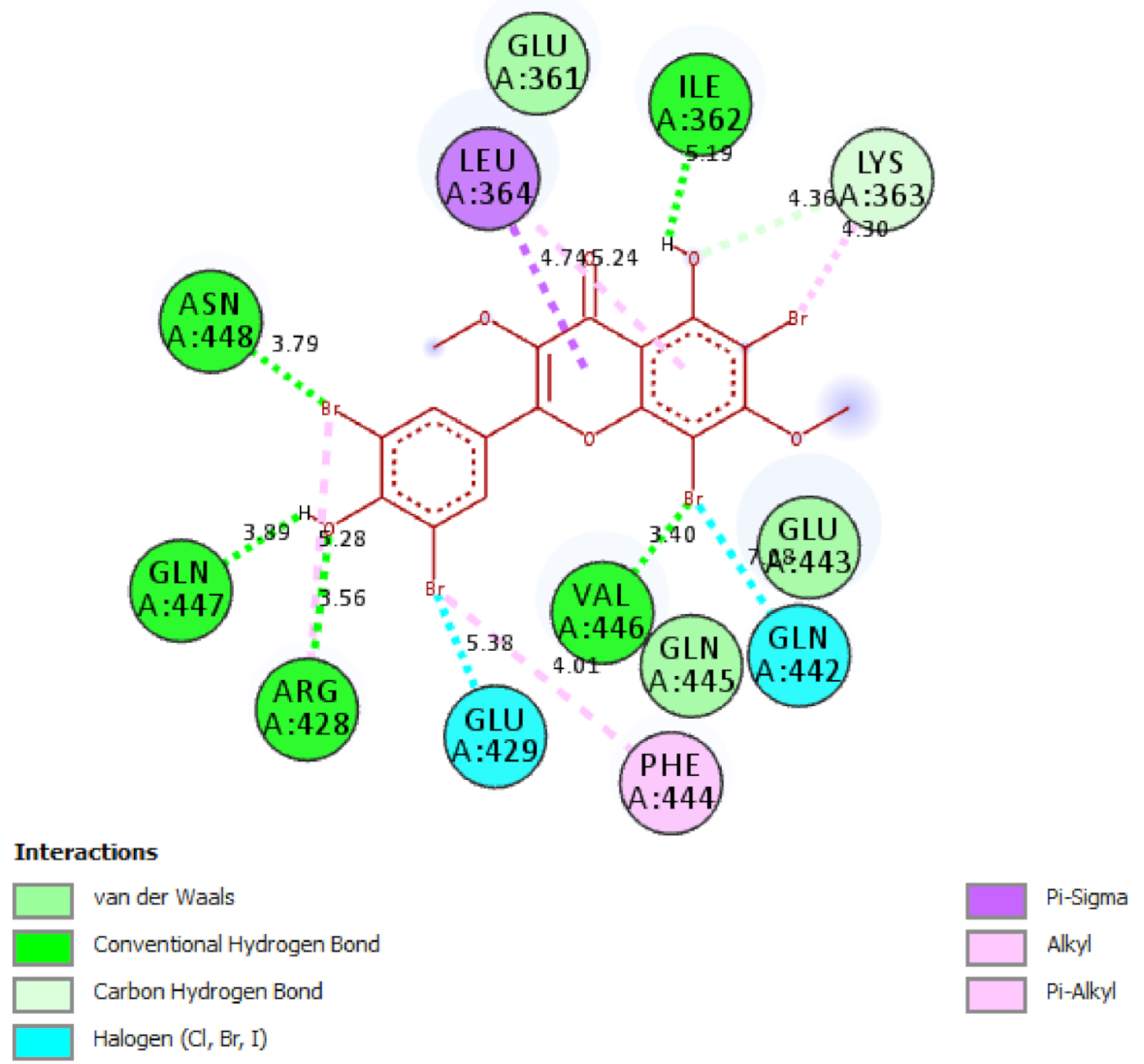

Figure 5. The most interactions between pose $\mathbf{1 1}$ and amino acids on receptor 4J5T were conducted. 


\section{Arg 428}

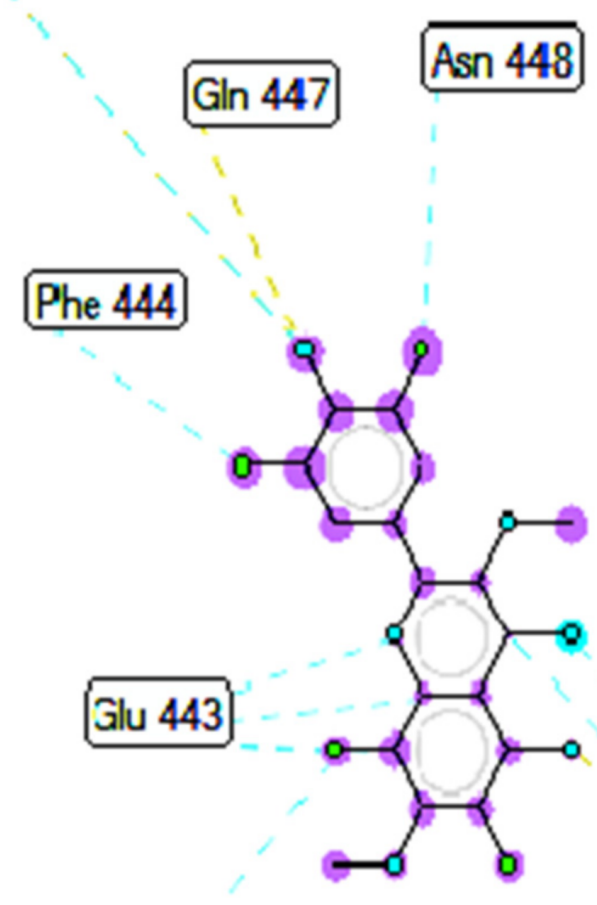

\section{Val 446}

Figure 6. The ligand map was formed by the conformation ligand of $\mathbf{1 1}$ and receptor $4 \mathrm{~J} 5 \mathrm{~T}$, a crystal structure of enzyme, alpha-glucosidase.

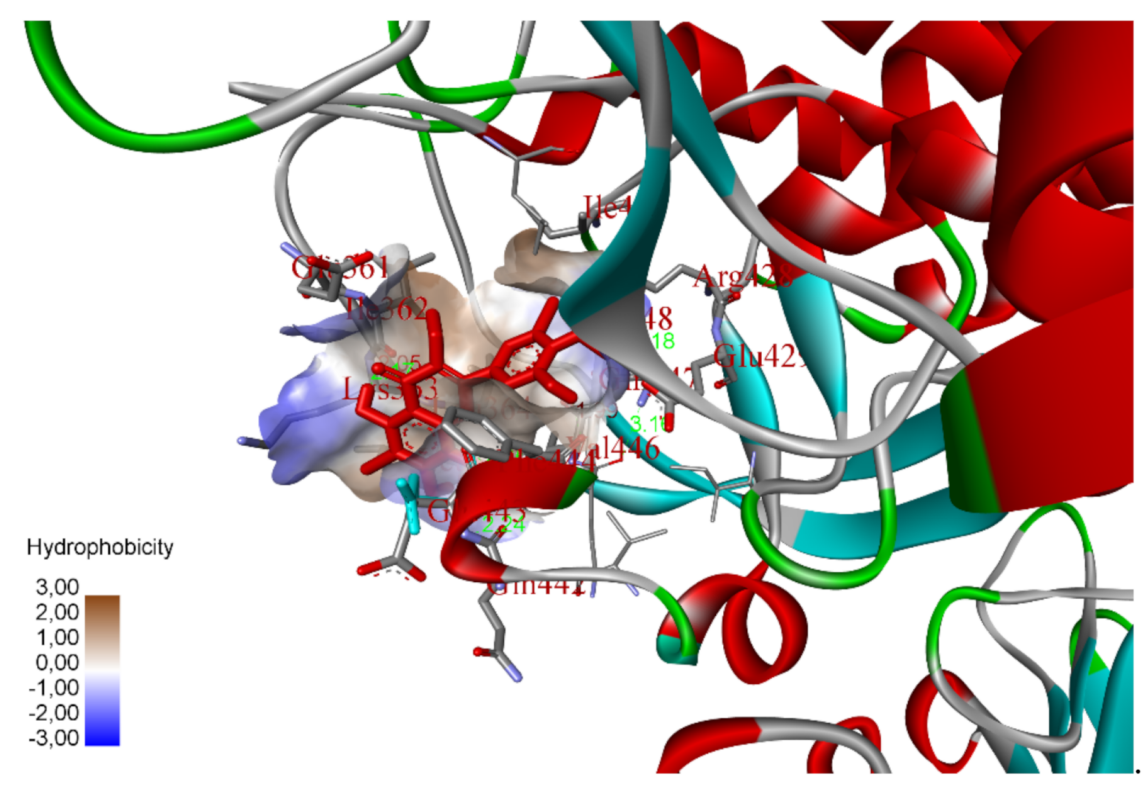

Figure 7. The most stable conformation ligand 8 was bound to active sites on the target enzyme at pocket of 4J5T: PDB (ligand: red color). 


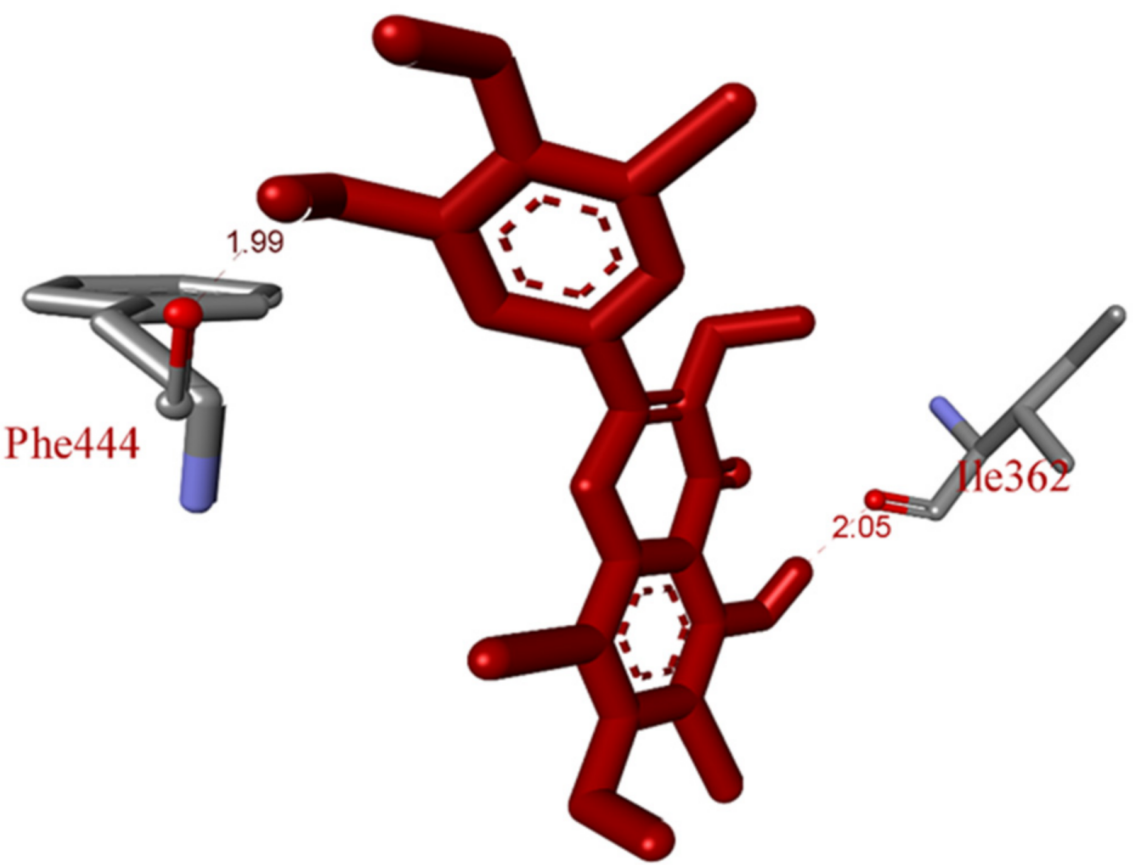

Figure 8. The hydrogen bonds were formed from residual amino acids of target enzyme 4J5T to functional groups on the most stable conformation ligand 8.

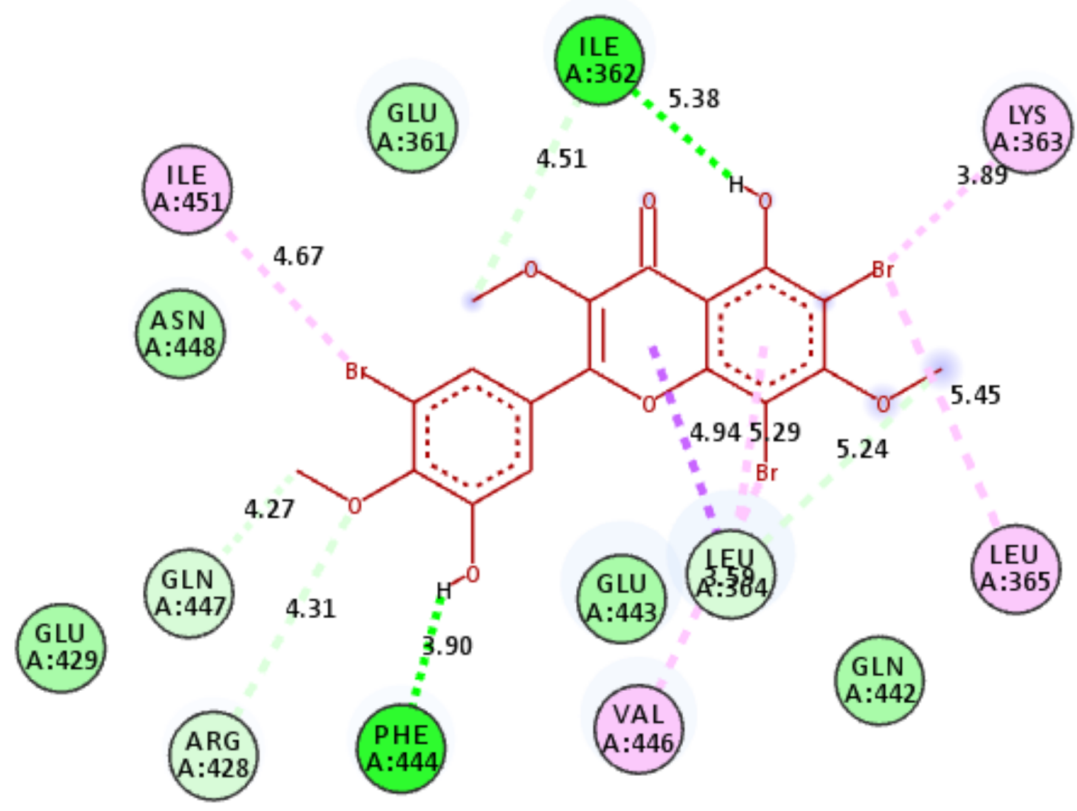

\section{Interactions}
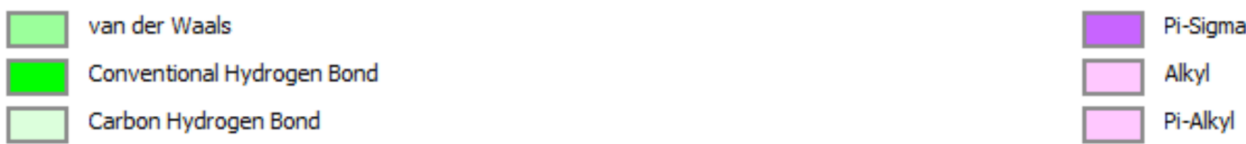

Figure 9. The most interactions were linked from pose 8 to amino acids on receptor $4 \mathrm{~J} 5 \mathrm{~T}$.

\section{Materials and Methods}

\subsection{Source of the Plant Material}

Leaves of Combretum quadrangulare were collected in Duc Hoa, Long An Province in March and April 2020. The plant was identified as Combretum quandrangulare Kurz by Dr. Tran Cong Luan, Tay Do University, Vietnam. A voucher specimen (No UE-002) was 
deposited in the herbarium of the Department of Organic Chemistry, Faculty of Chemistry, Ho Chi Minh University of Education, Ho Chi Minh City, Vietnam.

\subsection{Isolation and Structure Elucidation of the Compounds}

Gravity column chromatography was performed on silica gel $60(0.040-0.063 \mathrm{~mm}$, Merck, Darmstadt, Germany). TLC for checking chromatographic patterns of fractions and isolated compounds was carried out on silica gel $60 \mathrm{~F}_{254}$ (Merck) and spots were visualized by spraying with $10 \% \mathrm{H}_{2} \mathrm{SO}_{4}$ solution followed by heating. Specific rotations were obtained on a Jasco P-1010 polarimeter (Oklahoma City, OK, USA). The HR-ESI-MS were recorded on a MicroOTOF-Q mass spectrometer (Bruker, Billerica, MA, USA). The NMR spectra were measured on a Bruker Avance $500 \mathrm{MHz}$ spectrometer (Bruker, Billerica, MA, USA).

\subsection{Isolation}

Dried leaves of $C$. quadrangulare $(11 \mathrm{~kg}$ ) were crushed and extracted with $\mathrm{MeOH}$ $(3 \times 30 \mathrm{~L})$ at an ambient temperature for $24 \mathrm{~h}$. The filtrated solution was evaporated to dryness under reduced pressure to obtain a crude extract $(118.4 \mathrm{~g})$. This crude was successively partitioned by $n$-hexane, $n$-hexane: EtOAc $(1: 1, v / v)$, EtOAc, to afford $\mathbf{H}$ (29.1 g), HEA (160.3 g), EA (30.0 g), and MeOH (M, 12.0 g), respectively. Fraction HEA $(160.3 \mathrm{~g})$ was subjected to silica gel column chromatography (CC), using an isocratic mobile phase consisting of $n$-hexane: EtOAc: acetone $(5: 1: 1, v / v / v)$ to obtain nine fractions: P1 (4.95 g), P2 (9.72 g), P3 (6.94 g), P4 (4.82 g), P5 (5.69 g), P6 (4.23 g), P7 (3.2 g), P8 (4.15 g), and P9 (3.9 g). Fraction P2 (9.72 g) was subjected to silica gel column chromatography, using the solvent system of $n$-hexane: EtOAc: acetone (5:1:1, $v / v / v)$ to obtain fractions T1 (1.8 g), T2 (600.0 mg), T3 (900.0 mg), T4 (2.0 g), T5 (1.1 g), and T6 (1.3 g).

Fraction T1 (1.8 g) was submitted to silica gel CC, eluted by the solvent system $n$ hexane: $\mathrm{CHCl}_{3}$ : EtOAc: acetone (3:2:1:1, v/v/v/v) to obtain four fractions: T1.1 $(310.0 \mathrm{mg})$, T1.2 (560.0 mg), T1.3 (230.0 mg), and T1.4 (190.0 mg). Fraction T1.2 was rechromatographed, eluted with the same solvent system to obtain three compounds: 2 (55.2 mg), 7 (5.1 mg), and $14(2.1 \mathrm{mg})$. Fraction T5 $(1.1 \mathrm{~g})$ was submitted to silica gel CC using the mixture of $n$-hexane: $\mathrm{CHCl}_{3}$ : EtOAc: acetone (3:2:2:2, $\left.v / v / v / v\right)$ as a mobile phase to obtain three fractions, T5.1 (210.0 mg), T5.2 (350.0 mg), and T5.3 (150.0 mg). Fraction T5.1 was rechromatographed and eluted with the same solvent system to obtain two compounds: 1 (7.4 mg) and 3 $(45.0 \mathrm{mg})$. Fraction T5.2 was subjected to silica gel CC, eluted with the solvent system n-hexane: $\mathrm{CHCl}_{3}$ : EtOAc: acetone (4:3:3:1, $\left./ \mathrm{v} / \mathrm{v} / \mathrm{v}\right)$ to afford three compounds: 6 (4.7 mg), $12(3.8 \mathrm{mg})$ and $13(6.8 \mathrm{mg})$. Fraction T5.3 was rechromatographed using an isocratic mobile phase consisting of a $n$-hexane: $\mathrm{CHCl}_{3}$ : EtOAc: acetone: $\mathrm{H}_{2} \mathrm{O}(2: 2: 1: 1: 0.01, v / v / v / v / v)$ to gain two compounds, $4(5.1 \mathrm{mg})$ and $\mathbf{5}(4.7 \mathrm{mg})$. Fraction P9 was applied to Sephadex LH-20 gel chromatography and eluted with methanol to afford three fractions, P9.1-P9.3. Fraction P9.3 (601 mg) was fractionated by silica gel CC to afford compounds 15 (1.9 mg) and $16(2.7 \mathrm{mg})$.

\subsection{General Procedure to Synthesize Compounds 8-11}

In $4 \mathrm{~mL}$ of acetic acid, ayanin $(2,10 \mathrm{mg}, 0.029 \mathrm{mmol})$ and sodium bromide $(14.9 \mathrm{mg}$, $0.145 \mathrm{mmol}$ ) were dissolved at room temperature under stirring. The reaction was added to $0.02 \mathrm{~mL}(0.196 \mathrm{mmol})$ of $30 \%$ hydrogen peroxide. The reaction was conducted for $30 \mathrm{~min}$ and was periodically monitored by TLC. After neutralizing it with saturated sodium hydrogen carbonate, the mixture was extracted with ethyl acetate-water $(1: 1, v / v)$ to gain an organic layer. This was pooled, washed with brine, and dried over anhydrous $\mathrm{Na}_{2} \mathrm{SO}_{4}$. The residue was further absorbed onto column chromatography successively using the gradient system of $n$-hexane: chloroform $(1: 4, v / v)$ to afford 8 (14.9 $\mathrm{mg})$. The procedure followed the previous report with modifications [26].

In $4 \mathrm{~mL}$ of acetic acid, kamatakenin $(3,10 \mathrm{mg}, 0.032 \mathrm{mmol})$ and sodium bromide $(16.4 \mathrm{mg}, 0.160 \mathrm{mmol})$ were dissolved at room temperature under stirring. The reaction 
was added to $0.02 \mathrm{~mL}(0.196 \mathrm{mmol})$ of $30 \%$ hydrogen peroxide and was conducted in 30 min. The work-up followed the same procedure as mentioned previously to obtain the residue. The residue was further absorbed onto column chromatography successively using the gradient system of $n$-hexane: chloroform $(1: 4, v / v)$ to afford 11 (18.6 mg). The ratio of 3 and sodium bromide was modified to $1: 1$ and the reaction was repeated following the previously mention procedure. The reaction was conducted in $1 \mathrm{~h}$ and compounds 9 (4.4 mg) and $10(6.0 \mathrm{mg})$ were obtained after silica gel CC.

\subsubsection{6,8,5'-Tribromoayanin (8)}

Isolated yield 89.0\%; light yellow powder. UV (MeOH) $\lambda_{\max }(\log \varepsilon) 217$ (4.59), 257 (4.42), 360 (4.34) nm; IR cm ${ }^{-1}$ (KBr): 3389, 1670, 1626, 1575, 1405, 1372. ${ }^{1} \mathrm{H}$ NMR (500 MHZ, Acetone- $\left.d_{6}\right) \delta_{\mathrm{H}} 15.72(s, 1 \mathrm{H}, 5-\mathrm{OH}), 8.18\left(d, 1 \mathrm{H}, \mathrm{J}=2.0 \mathrm{~Hz}, \mathrm{H}-6^{\prime}\right), 7.87(d, 1 \mathrm{H}, \mathrm{J}=1.5 \mathrm{~Hz}$, $\left.\mathrm{H}-2^{\prime}\right), 3.99\left(s, 3 \mathrm{H}, 7-\mathrm{OCH}_{3}\right), 3.97\left(\mathrm{~s}, 3 \mathrm{H}, 4^{\prime}-\mathrm{OCH}_{3}\right), 3.79\left(\mathrm{~s}, 3 \mathrm{H}, 3-\mathrm{OCH}_{3}\right) .{ }^{13} \mathrm{C} \mathrm{NMR}(125 \mathrm{MHz}$, Acetone- $\left.d_{6}\right) \delta_{\mathrm{C}} 178.8(\mathrm{C}-4), 172.6(\mathrm{C}-7), 161.4(\mathrm{C}-5), 160.6$ (C-9), $156.6(\mathrm{C}-2), 152.3\left(\mathrm{C}-4^{\prime}\right)$, $149.5\left(\mathrm{C}-3^{\prime}\right), 139.7(\mathrm{C}-3), 127.3(\mathrm{C}-6), 122.1\left(\mathrm{C}-1^{\prime}\right), 110.9\left(\mathrm{C}-2^{\prime}\right), 109.8(\mathrm{C}-10), 97.0\left(\mathrm{C}-5^{\prime}\right), 94.0$ (C-6), $88.7(\mathrm{C}-8), 61.6\left(7-\mathrm{CH}_{3}\right), 60.2\left(3-\mathrm{CH}_{3}\right), 56.6\left(4^{\prime}-\mathrm{CH}_{3}\right)$. HR-ESI-MS m/z 576.8133 (calcd. for $\left.\mathrm{C}_{18} \mathrm{H}_{12} \mathrm{O}_{7} \mathrm{Br}_{3}, 576.8133\right)$.

\subsubsection{8-Bromokamatakenin (9)}

Isolated yield 35.1\%; light yellow powder. UV (MeOH) $\lambda_{\max }(\log \varepsilon) 206$ (4.32), 258 (4.29), 360 (4.16) nm; IR cm ${ }^{-1}$ (KBr): 3389, 1670, 1626, 1575, 1405, 1372. ${ }^{1} \mathrm{H}$ NMR (DMSO- $d_{6}$ ) $\delta_{\mathrm{H}} 12.85(s, 1 \mathrm{H}, 5-\mathrm{OH}), 10.39\left(\mathrm{~s}, 1 \mathrm{H}, 4^{\prime}-\mathrm{OH}\right), 8.07\left(d, 2 \mathrm{H}, \mathrm{H}-2^{\prime}, 6^{\prime}\right), 6.98\left(d, \mathrm{~J}=9.0 \mathrm{~Hz}, \mathrm{H}-3^{\prime}, 5^{\prime}\right)$, $3.97\left(\mathrm{~s}, 3 \mathrm{H}, 7-\mathrm{OCH}_{3}\right), 3.82\left(\mathrm{~s}, 3 \mathrm{H}, 3-\mathrm{OCH}_{3}\right) .{ }^{13} \mathrm{C} \mathrm{NMR}\left(125 \mathrm{MHz}, \mathrm{DMSO}-d_{6}\right) \delta_{\mathrm{C}} 178.0(\mathrm{C}-4)$, 161.3 (C-7), 160.7 (C-5), 160.6 (C-4'), 155.8 (C-2), 151.7 (C-9), 137.6 (C-3), 130.3 (C-2', 6' $)$, $120.4\left(\mathrm{C}-1^{\prime}\right), 115.7\left(\mathrm{C}-3^{\prime}, 5^{\prime}\right), 105.5(\mathrm{C}-10), 96.1(\mathrm{C}-6), 87.0(\mathrm{C}-8), 59.7\left(3-\mathrm{OCH}_{3}\right), 57.3\left(7-\mathrm{OCH}_{3}\right)$. HR-ESI-MS $m$ / z 390.9831 (calcd. for $\mathrm{C}_{17} \mathrm{H}_{12} \mathrm{O}_{6} \mathrm{Br}, 390.9817$ ).

\subsubsection{6-Bromokamatakenin (10)}

Isolated yield 47.6\%; light yellow powder. UV (MeOH) $\lambda_{\max }(\log \varepsilon) 208(4.19), 271$ (4.02), 343 (3.99) nm; IR cm ${ }^{-1}$ (KBr): 3389, 1670, 1626, 1575, 1405, 1372. ${ }^{1} \mathrm{H} \mathrm{NMR}\left(\mathrm{DMSO}-d_{6}\right)$ $\delta_{\mathrm{H}} 13.47(\mathrm{~s}, 1 \mathrm{H}, 5-\mathrm{OH}), 10.34\left(\mathrm{~s}, 1 \mathrm{H}, 4^{\prime}-\mathrm{OH}\right), 8.02\left(d, 2 \mathrm{H}, \mathrm{H}-2^{\prime}, 6^{\prime}\right), 7.03(s, \mathrm{H}-8), 6.96(d, \mathrm{~J}=9.0$ $\left.\mathrm{Hz}, \mathrm{H}-3^{\prime}, 5^{\prime}\right), 3.98\left(s, 3 \mathrm{H}, 7-\mathrm{OCH}_{3}\right), 3.82\left(s, 3 \mathrm{H}, 3-\mathrm{OCH}_{3}\right) .{ }^{13} \mathrm{C}$ NMR $\left(125 \mathrm{MHz}, \mathrm{DMSO}-d_{6}\right)$ $\delta_{\mathrm{C}} 177.6(\mathrm{C}-4), 161.5(\mathrm{C}-5), 160.8(\mathrm{C}-7), 160.5\left(\mathrm{C}-4^{\prime}\right), 156.3$ (C-9), 155.3 (C-2), 138.9 (C-3), 130.3 $\left(\mathrm{C}-2^{\prime}, 6^{\prime}\right), 120.3\left(\mathrm{C}-1^{\prime}\right), 115.7\left(\mathrm{C}-3^{\prime}, 5^{\prime}\right), 105.6(\mathrm{C}-10), 99.7(\mathrm{C}-6), 95.0(\mathrm{C}-8), 59.7\left(3-\mathrm{OCH}_{3}\right), 57.3$ $\left(7-\mathrm{OCH}_{3}\right)$. HR-ESI-MS $m / z 390.9843$ (calcd. for $\mathrm{C}_{17} \mathrm{H}_{12} \mathrm{O}_{6} \mathrm{Br}, 390.9817$ )

\subsubsection{6,8,3', $5^{\prime}$-Tetrabromokamatakenin (11)}

Isolated yield 93.0\%; light yellow powder. UV (MeOH) $\lambda_{\max }(\log \varepsilon) 211$ (4.46), 254 (4.11), 416 (4.18) nm; IR cm ${ }^{-1}$ (KBr): 3389, 1670, 1626, 1575, 1405, 1372. ${ }^{1} \mathrm{H} \mathrm{NMR}\left(\mathrm{DMSO}-d_{6}\right)$ $\delta_{\mathrm{H}} 13.41(s, 1 \mathrm{H}, 5-\mathrm{OH}), 8.28\left(\mathrm{~s}, 2 \mathrm{H}, \mathrm{H}-2^{\prime}, 6^{\prime}\right), 3.92\left(\mathrm{~s}, 3 \mathrm{H}, 7-\mathrm{O} \mathrm{CH}_{3}\right), 3.87\left(\mathrm{~s}, 3 \mathrm{H}, 3-\mathrm{OCH}_{3}\right) \cdot{ }^{13} \mathrm{C}$ NMR (126 MHz, DMSO-d 6 ) $\delta_{\mathrm{C}} 177.7$ (C-4), 166.2 (C-7), 161.7 (C-5), $161.2\left(\mathrm{C}-4^{\prime}\right), 159.2(\mathrm{C}-9)$, 156.9 (C-2), 138.5 (C-3), $132.2\left(\mathrm{C}-2^{\prime}, 6^{\prime}\right), 121.2\left(\mathrm{C}-1^{\prime}\right), 112.2\left(\mathrm{C}-3^{\prime}, 5^{\prime}\right), 108.7$ (C-10), 99.3 (C-6), 94.7 (C-8), $60.7\left(3-\mathrm{O} \mathrm{CH}_{3}\right), 59.5\left(7-\mathrm{O} \mathrm{CH}_{3}\right)$. HR-ESI-MS m/z 624.7127 (calcd. for $\mathrm{C}_{17} \mathrm{H}_{9} \mathrm{O}_{6} \mathrm{Br}_{4}$, 624.7133).

\subsection{Alpha-Glucosidase Inhibition Assay}

The alpha-glucosidase $(0.2 \mathrm{U} / \mathrm{mL})$ and substrate $(5.0 \mathrm{mM}$-nitrophenyl- $\alpha$-D-glucopyranoside) were dissolveed in $100 \mathrm{mM}$ of $\mathrm{pH} 6.9$ sodium phosphate buffer [27]. The inhibitor $(50 \mu \mathrm{L})$ was preincubated with alpha-glucosidase at $37^{\circ} \mathrm{C}$ for $20 \mathrm{~min}$, and then the substrate $(40 \mu \mathrm{L})$ was added to the reaction mixture. The enzymatic reaction was carried out at $37^{\circ} \mathrm{C}$ for $20 \mathrm{~min}$ and stopped by adding $0.2 \mathrm{M}$ of $\mathrm{Na}_{2} \mathrm{CO}_{3}(130 \mu \mathrm{L})$. Enzymatic activity was quantified by measuring absorbance at $405 \mathrm{~nm}$. All samples were analyzed in triplicate at 
five different concentrations around the $\mathrm{IC}_{50}$ values, and the mean values were retained. The inhibition percentage (\%) was calculated by the following equation:

$$
\text { Inhibition }(\%)=[1-(\text { Asample/Acontrol })] \times 100 \text {. }
$$

\subsection{Inhibitory Type Assay of $\mathbf{8}$ and $\mathbf{1 1}$ on Alpha-Glucosidase}

The mechanisms of inhibition of alpha-glucosidase by $\mathbf{8}$ and $\mathbf{1 1}$ were determined by Lineweaver-Burk plots (Microsoft Excel 2010, Washington, WA, USA), using methods similar to those reported in the literature [28]. Enzyme inhibition due to various concentrations of the $\mathbf{8}$ and $\mathbf{1 1}$ compounds were evaluated by monitoring the effects of different concentrations of the substrate. For Lineweaver-Burk double reciprocal plots 1 /enzyme velocity $(1 / \mathrm{V})$ vs. $1 /$ substrate concentration $(1 /[\mathrm{S}])$, the inhibition type was determined using various concentrations of $p \mathrm{NPG}(1 \mathrm{mM}, 2 \mathrm{mM}$, and $4 \mathrm{mM})$ as a substrate in the presence of different concentrations of the test compounds $(0 ; 4.96 ; 9.92$ and $19.84 \mu \mathrm{M}$ for 8 and $0 ; 21.62 ; 43.03$ and $86.06 \mu \mathrm{M}$ for 11). The experiments were carried out in 3 replicates. The mixtures were incubated at $37^{\circ} \mathrm{C}$ and the optical density was measured at $405 \mathrm{~nm}$ every $1 \mathrm{~min}$ for $30 \mathrm{~min}$ with the Clariostar Labtech microplate reader (Ortenberg, Germany). Optimal concentrations of the tested compound were chosen based on the $\mathrm{IC}_{50}$ value. The inhibition constants were obtained graphically from secondary plots (Microsoft Excel 2010, Washington, WA, USA).

\subsection{Antibacterial Activity Assay}

Methicillin-resistant Staphylococcus aureus (MRSA), extended spectrum beta-lactamaseproducing Escherichia coli (ESBL-producing E. coli) and the agar well diffusion method were used to evaluate the antibacterial activity of the isolated compounds [29]. The strains were cultured in nutrient broth at $37^{\circ} \mathrm{C}$ for $18 \mathrm{~h}$ and diluted with steriled $0.9 \% \mathrm{NaCl}$ to obtain the $1.5 \times 10^{8} \mathrm{CFU} / \mathrm{mL}$ bacterial solution. Then, $100 \mu \mathrm{L}$ of the bacterial solution was spread on Mueller-Hinton agar (MHA) plate on which 8-mm wells were created aseptically with tips. The isolated compounds were dissolved in dimethyl sulfoxide at the concentration of $1 \mathrm{mg} / \mathrm{mL}$ and $50 \mu \mathrm{L}$ of each compound solution was applied in each well. The plates were incubated at $37^{\circ} \mathrm{C}$ for $16-18 \mathrm{~h}$ and the diameters of the inhibtion zones were measured. Dimethyl sulfoxide and apramycin were used as controls in this experiment.

\subsection{Molecular Docking Study Method}

The calculations of the molecular docking model were performed according to the procedure in the supporting information file and followed the previous article [30].

\section{Conclusions}

From the Vietnamese plant $C$. quadrangulare, twelve alpha-glucosidase inhibitors were isolated and elucidated, including 5-hydroxy-3,7,4'-trimethoxyflavone (1), ayanin (2), kamatakenin (3), rhamnocitrin (4), ombuin (5), myricetin-3,7,3',5'-tetramethyl ether (6), gardenin D (7), luteolin (12), apigenin (13), mearnsetin (14), isoorientin (15), and vitexin (16). To the best of our knowledge, compounds 4-7 and 12-14 were reported for the first time from C. quadrangulare. New synthetic analogues 8-11 were prepared via electrophic bromination of compounds 2 and 3 . Compounds 4 and 5 showed moderate antibacterial activity against methicillin-resistant Staphylococcus aureus. Compounds 2, 4, 6-9, and 11-14 displayed good alpha-glucosidase inhibition, with $\mathrm{IC}_{50}$ values in the range of 30.5$282.0 \mu \mathrm{M}$. Among them, synthetic compounds revealed the strongest inhibition. The kinetic of enzyme inhibition showed that $\mathbf{8}$ and $\mathbf{1 1}$ were noncompetitive type inhibition against alpha-glucosidase. An in silico molecular docking model indicated that compounds $\mathbf{8}$ and $\mathbf{1 1}$ were potent alpha-glucosidase inhibitors.

Supplementary Materials: The following are available online at Table S1. ${ }^{1} \mathrm{H}$ NMR $(500 \mathrm{MHz})$ data of isolated flavonones, Table S2. ${ }^{13} \mathrm{C}-\mathrm{NMR}(125 \mathrm{MHz})$ data of isolated flavonoids, Table S3. NMR comparison of $\mathbf{2}$ and 8, Table S4. NMR comparison of 3, 9-11, Table S5. The significant results in 
silico molecular docking model of conformation ligands, docking poses, Table S6. Alpha-glucosidase inhibitory activity of fractions, Figure S1. Isolation scheme of compounds from Combretum quadrangulare KurZ., Figures S2-S4. Spectral characterization of 8, Figures S5-S7. Spectral characterization of 9, Figures S8-S10. Spectral characterization of 10, Figures S11-S13. Spectral characterization of 11, Figures S14-S21. IR and UV spectra of 8-11, Figures S22-S27. Docking data of 8 and 11.

Author Contributions: Conceptualization, T.-B.-N.D., T.-H.D. and C.-L.T.; methodology, T.-H.D., V.-Q.N. and T.-H.-T.N.; software, H.-H.N. and C.-L.T.; formal analysis, T.-H.D., C.-L.T., T.-B.-N.D., T.-M.-T.N. and N.-M.-A.T.; investigation, T.-B.-N.D. and T.-H.D.; resources, C.-L.T., C.H.N., T.-H.D. and J.S.; data curation, T.-B.-N.D., T.-M.-T.N., T.-M.-D.T. and N.-M.-A.T.; writing-original draft preparation, T.-H.D., T.-B.-N.D., T.-H.-T.N. and H.-H.N.; writing-review and editing, C.-L.T., T.-H.D. and J.S.; supervision, T.-H.D. and C.-L.T. All authors have read and agreed to the published version of the manuscript.

Funding: This study was supported by the Vietnam Ministry of Education and Training (B2021-SPS03-HH).

Institutional Review Board Statement: Not Applicable.

Informed Consent Statement: Not Applicable.

Data Availability Statement: The data presented in this study are available in Supplementary Material.

Conflicts of Interest: The authors declare no conflict of interest.

Sample Availability: Samples of the compounds are not available from the authors.

\section{References}

1. Adnyana, I.K.; Tezuka, Y.; Banskota, A.H.; Tran, K.Q.; Kadota, S. Hepatoprotective Constituents of the Seeds of Combretum quadrangulare. Biol. Pharm. Bull. 2000, 23, 1328-1332. [CrossRef] [PubMed]

2. Banskota, A.; Tezuka, Y.; Tran, Q.; Kadota, S. Chemical Constituents and Biological Activities of Vietnamese Medicinal Plants. Curr. Top. Med. Chem. 2003, 3, 227-248. [CrossRef] [PubMed]

3. Ganzera, M.; Ellmerer-Müller, E.P.; Stuppner, H. Cycloartane triterpenes from Combretum quadrangulare. Phytochemistry 1998, 49, 835-838. [CrossRef]

4. Banskota, A.H.; Tezuka, Y.; Phung, L.K.; Tran, K.Q.; Saiki, I.; Miwa, Y.; Taga, T.; Kadota, S. Cytotoxic cycloartane-type triterpenes from Combretum quadrangulare. Bioorg. Med. Chem. Lett. 1998, 8, 3519-3524. [CrossRef]

5. Banskota, A.H.; Tezuka, Y.; Tran, K.Q.; Tanaka, K.; Saiki, I.; Kadota, S. Thirteen novel cycloartane-type triterpenes from Combretum quadrangulare. J. Nat. Prod. 1999, 63, 57-64. [CrossRef] [PubMed]

6. Banskota, A.H.; Tezuka, Y.; Tran, K.Q.; Tanaka, K.; Saiki, I.; Kadota, S. Methyl Quadrangularates A-D and Related Triterpenes from Combretum quadrangulare. Chem. Pharm. Bull. 2000, 48, 496-504. [CrossRef] [PubMed]

7. Adnyana, I.K.; Tezuka, Y.; Awale, S.; Banskota, A.H.; Tran, K.Q.; Kadota, S. Quadranosides VI-XI, Six New Triterpene Glucosides from the Seeds of Combretum quadrangulare. Chem. Pharm. Bull. 2000, 48, 1114-1120. [CrossRef] [PubMed]

8. Adnyana, I.K.; Tezuka, Y.; Banskota, A.H.; Tran, K.Q.; Kadota, S. Three new triterpenes from the seeds of Combretum quadrangulare and their hepatoprotective activity. J. Nat. Prod. 2001, 64, 360-363. [CrossRef]

9. $\quad$ Banskota, A.H.; Tezuka, Y.; Adnyana, I.K.; Xiong, Q.; Hase, K.; Tran, K.Q.; Tanak, K.; Saiki, I.; Kadota, S. Hepatoprotective Effect of Combretum quadrangulare and Its Constituents. Biol. Pharm. Bull. 2000, 23, 456-460. [CrossRef]

10. Toume, K.; Nakazawa, T.; Ohtsuki, T.; Arai, M.A.; Koyano, T.; Kowithayakorn, T.; Ishibashi, M. Cycloartane triterpenes isolated from Combretum quadrangulare in a screening program for death-receptor expression enhancing activity. J. Nat. Prod. 2011, 74, 249-255. [CrossRef]

11. Duong, T.-H.; Bui, X.-H.; Le Pogam, P.; Nguyen, H.-H.; Tran, T.-T.; Nguyen, T.-A.-T.; Chavasiri, W.; Boustie, J.; Nguyen, K.-P.-P. Two novel diterpenes from the roots of Phyllanthus acidus (L.) Skeel. Tetrahedron 2017, 73, 5634-5638. [CrossRef]

12. Duong, T.-H.; Beniddir, M.A.; Nguyen, V.-K.; Aree, T.; Gallard, J.-F.; Mac, D.-H.; Nguyen, H.-H.; Bui, X.-H.; Boustie, J.; Nguyen, K.-P.-P.; et al. Sulfonic Acid-Containing Flavonoids from the Roots of Phyllanthus acidus. J. Nat. Prod. 2018, 81, 2026-2031. [CrossRef]

13. Nguyen, T.-A.-T.; Duong, T.-H.; Le Pogam, P.; Beniddir, M.A.; Nguyen, H.-H.; Do, T.-M.-L.; Nguyen, K.-P.-P. Two new triterpenoids from the roots of Phyllanthus emblica. Fitoterapia 2018, 130, 140-144. [CrossRef]

14. Macedo, I.; Da Silva, J.H.; Da Silva, P.T.; Cruz, B.G.; Vale, J.P.D.; Dos Santos, H.S.; Bandeira, P.N.; De Souza, E.B.; Xavier, M.R.; Coutinho, H.D.; et al. Structural and Microbiological Characterization of 5-Hydroxy-3,7,4'-Trimethoxyflavone: A Flavonoid Isolated from Vitex gardneriana Schauer Leaves. Microb. Drug Resist. 2019, 25, 434-438. [CrossRef]

15. Rahman, A.; Mahardika, I.; Saputri, R.D.; Tjahjandarie, T.S.; Tanjung, M. Isolasi, karakterisasi, dan uji aktivitas antioksidan senyawa turunan kuersetin dari kulit batang melicope quercifolia. J. Sains Dan Kesehat. 2020, 2, 413-417. 
16. A Castillo, Q.; Triana, J.; Eiroa, J.L.; Padrón, J.M.; Plata, G.B.; Abel-Santos, E.V.; Báez, L.A.; Rodríguez, D.C.; A Jiménez, M.; Pérez-Pujols, M.F. Flavonoids from Eupatorium illitum and Their Antiproliferative Activities. Pharmacogn. J. 2015, 7, 178-181. [CrossRef]

17. Tu, Y.-C.; Lian, T.-W.; Yen, J.-H.; Chen, Z.-T.; Wu, M.-J. Antiatherogenic Effects of Kaempferol and Rhamnocitrin. J. Agric. Food Chem. 2007, 55, 9969-9976. [CrossRef]

18. Salem, M.M.; Hussein, S.R.; El-Sharawy, R.; El-Khateeb, A.; Ragab, E.A.; Dawood, K.M.; El Negoumy, S.I.M. Antioxidant and antiviral activities of the aqueous alcoholic leaf extract of Boscia angustifolia A. Rich. (Capparaceae) and its major component 'ombuin'. Egypt. Pharm. J. 2016, 15, 1.

19. Kranjc, E.; Albreht, A.; Vovk, I.; Makuc, D.; Plavec, J. Non-targeted chromatographic analyses of cuticular wax flavonoids from Physalis alkekengi L. J. Chromatogr. A 2016, 1437, 95-106. [CrossRef]

20. Zheng, J.; Song, M.; Dong, P.; Qiu, P.; Guo, S.; Zhong, Z.; Li, S.; Ho, C.-T.; Xiao, H. Identification of novel bioactive metabolites of 5-demethylnobiletin in mice. Mol. Nutr. Food Res. 2013, 57, 1999-2007. [CrossRef] [PubMed]

21. Da Silva, L.A.L.; Faqueti, L.G.; Reginatto, F.H.; Dos Santos, A.D.C.; Barison, A.; Biavatti, M.W. Phytochemical analysis of Vernonanthura tweedieana and a validated UPLC-PDA method for the quantification of eriodictyol. Rev. Bras. Farm. 2015, 25, 375-381. [CrossRef]

22. Arriffin, N.M.; Jamil, S.; Basar, N.; Khamis, S.; Abdullah, S.A.; Lathiff, S.M.A. Phytochemical studies and antioxidant activities of Artocarpus scortechinii King. Rec. Nat. Prod 2017, 11, 299-303.

23. Oladimeji, A.O.; Oladosu, I.A.; Ali, M.S.; Ahmed, Z. Flavonoids from the roots of Dioclea reflexa (Hook F.). Bull. Chem. Soc. Ethiop. 2015, 29, 441. [CrossRef]

24. Peng, X.; Zheng, Z.; Cheng, K.-W.; Shan, F.; Ren, G.-X.; Chen, F.; Wang, M. Inhibitory effect of mung bean extract and its constituents vitexin and isovitexin on the formation of advanced glycation endproducts. Food Chem. 2008, 106, $475-481$. [CrossRef]

25. Peng, J.; Fan, G.; Wu, Y.; Chen, H. Isalation and separation isoorientin and isovitexin from Patrinia villosa juss by high speed counter-current chromatography. Fenxi Huaxue 2005, 33, 1389-1392.

26. Narender, N.; Srinivasu, P.; Kulkarni, S.J.; Raghavan, K. V Liquid phase regioselective bromination of aromatic com-pounds over HZSM-5 catalyst. Synth. Commun. 2000, 30, 3669-3675. [CrossRef]

27. Devi, A.P.; Duong, T.-H.; Ferron, S.; Beniddir, M.A.; Dinh, M.-H.; Nguyen, V.-K.; Pham, N.-K.-T.; Mac, D.-H.; Boustie, J.; Chavasiri, W.; et al. Salazinic Acid-Derived Depsidones and Diphenylethers with $\alpha$-Glucosidase Inhibitory Activity from the Lichen Parmotrema dilatatum. Planta Medica 2020, 86, 1216-1224. [CrossRef]

28. Tran, C.-L.; Dao, T.-B.-N.; Tran, T.-N.; Mai, D.-T.; Tran, T.-M.-D.; Tran, N.-M.-A.; Dang, V.-S.; Vo, T.-X.; Duong, T.-H.; Sichaem, J. Alpha-Glucosidase Inhibitory Diterpenes from Euphorbia antiquorum Growing in Vietnam. Molecules 2021, 26, 2257. [CrossRef]

29. Prastiyanto, M.E.; Tama, P.D.; Ananda, N.; Wilson, W.; Mukaromah, A.H. Antibacterial Potential of Jatropha sp. Latex against Multidrug-Resistant Bacteria. Int. J. Microbiol. 2020, 2020, 1-6. [CrossRef]

30. Duong, T.-H.; Devi, A.P.; Tran, N.-M.-A.; Phan, H.-V.-T.; Huynh, N.-V.; Sichaem, J.; Tran, H.-D.; Alam, M.; Nguyen, T.-P.; Nguyen, H.-H.; et al. Synthesis, $\alpha$-glucosidase inhibition, and molecular docking studies of novel $\mathrm{N}$-substituted hydrazide derivatives of atranorin as antidiabetic agents. Bioorg. Med. Chem. Lett. 2020, 30, 127359. [CrossRef] 